\title{
Effect of foreign institutional investors on corporate board attributes: A literature review.
}

\author{
Sandeep Rao* \\ Department of Accounting and Finance, Strathclyde Business School, University of Strathclyde, Glasgow, United \\ Kingdom
}

\begin{abstract}
This paper is a review of the exiting literature on corporate governance focusing on the key attributes of board namely the executive compensation, board independence and board busyness. The paper looks into the exiting work on how the foreign investment impacts the corporate governance and the main theories supporting it. The paper provides a research setup for conducting future empirical studies specific to an economy on the impact of different types of foreign institutional investors on the corporate governance through the channel of board attributes. It provides a detailed discussion on how the endogeneity issues are addressed by previous literature and what new empirical research in governance can look forward to.
\end{abstract}

Keywords: Foreign investor impact, Executive compensation, Board independence, Board busyness.

Accepted on June 25, 2018

\section{Introduction}

Turnbull defines corporate governance as "all the influences affecting the institutional processes, including those for appointing the controllers and/or regulators, involved in organizing the production and sale of goods and services" [1]. Some authors specifically look at the corporate governance as the functioning of the board [2,3] and ownership interest [4].

The theory of agency is often discussed in the context of corporate governance, where the separation of ownership and management results in conflicting interest of managers who seek maximization of personal welfare [5]. Expropriation by managers and state, defined as "twin agency" problems [6] is also an important concern.

A key determinant of good governance is ownership structure of the firm. The ownership structure can broadly be classified as domestic investor and foreign investor ownership. Institutional investors form an important external control mechanism of governance. Several factors can determine how the ownership is structured and what can affect the changes in the shareholding patterns in a firm. In this context $\mathrm{Ni}$, Liao and Huang [7] study Taiwanese firms with either positive or negative change of foreign institutional shareholdings ratio and provide evidence that corporate governance and financial issues may not be the main concerns in shareholding change of foreign institutions.

Despite institutional differences across markets, the institutional monitoring plays a key role in influencing corporate governance [8]. Borochin and Yang [9] find that different institutional ownership has different impacts on the governance and firm valuation. They find that dedicated, and not transient investors, reduce firm misvaluations and the portfolio turnover drives governance effects. In the context of Japanese firms, Yoshikawa et al. [10], study the factors that those influences for and against change in corporate governance in Japan, and report the diffusion of corporate governance innovation across firms. They argue that corporate governance systems in Japanese firms neither fully converge to, nor completely diverge from, the Anglo-American model. In the context of Sweden's formal entry to the European union Fogel et al. [11], provide evidence that the corporate governance improvements in Swedish firms leading to increase in firm valuations occurred not just when the foreign institutional investments increased, but when this increase was more than the largest domestic shareholder providing them a critical "voice" in management through their voting.

Prior studies provide evidence of linkages between the institutional ownership and reduction in earnings management [11]; shareholder value $[12,13]$; improved governance [14]; better disclosures by management leading to reduced information asymmetry [15]; pay-for-performance executive compensation sensitivity and level of compensation [16] and even clean energy consumption [17]. These studies provide evidence of the monitoring role of the institutions in mitigating the agency problems. However, very little empirical studies in emerging markets exist which clearly establishes the role of different institutional investors as monitors of corporate governance.

\section{Theoretical Underpinning}

There is a legion of literature which has documented that the institutional investors are more informed and therefore help in providing the informativeness of prices in turn making the markets more efficient [18-20]. The price acts as a channel 
through which the institutional investors carryout firm monitoring resulting in corporate governance improvements [21]. Foreign institutions can action their monitoring by either "voting with their feet" [22], that is exit the stock [23$25]$; through investor activism [11,26,27] or by relationship investing [28,29].

Rational investor's preference towards corporations in which they have sufficient information has been modelled by Merton [30]. Dahlquist and Robertsson [31] show that foreign investors prefer large firms because they are more recognised and can be a proxy of information asymmetries. Again considering the agency issue, where higher expropriation by the managers is expected, investors are hesitant to make investments resulting in more concentration of holdings by non-outsiders [32]. Using China's split-share structure reform data, Huang and Zhu [33] find that Qualified Foreign Institutional Investors (QFIIs) have greater influence over the controlling state shareholders than local mutual funds. They also provide evidence in this emerging market context that involving foreign institutional investors significantly reduce expropriation by controlling shareholders, thus improving corporate governance. Due to the lack of risk sharing stock prices of these companies may be undervalued [30] and the protection offered to external investors may be positively associated with liquidity [34].

At theoretical level there are questions raised on whether liquidity actually hinders effective corporate governace $[35,36]$. Causal empirical studies tend to suggest that investors who receive adverse information on their holding companies prefer exit strategy in highly liquid stocks and 'hold and vote' strategy in less liquid. The hold and voice strategy is adopted to exert pressure on the management to change policies resulting in better returns. However, Maug [37] argues that liquidity and control trade-off does not exist. The author shows that liquid markets can enable large shareholders to exercise corporate control and rectify managerial failure. Formal models showing the possibility of large influential shareholders to generate profit from stocks at low value due to their monitoring actions are developed by Maug [37] and Kahn and Winton [38]. These models also disucss the free-rider issues faced by such shareholders.

"Stock price informativeness refers to the extent that stock prices reflect all available information" [39]. As the institutional investors (specifically the foreign institutional investors-foreign investors have long-term information advantage when compared to their domestic counterparts [40]) have specialised skills and techniques to monitor the firms, their ownership and trading patters can provide more informativeness in the stocks. Various studies have shown that the foreign invetors are able to influence the firm to be more transperant in information disclosures and thus are able to reduce the agency problems leading to promotion of better governance [39,41-47]. Khanna and Thomar [48] show that lower stock informativess is associated with poor corporate governance and lower transparancy.
In summary these studies provide adequate support for the proposition that foreign institutional ownership is associated with improved stock price informativeness, which is channelled through better monitoring, influencing corporate boards to adopt strategies that will improve the value to the investors [49]. Ferreira et al. [50] develop a simple model that shows a link between board's monitoring and stock price informativeness.

Several studies exist which contribute to the literature concerning the role of foreign institutional investors in emerging markets on liquidity [51-53], price information asymmetry [54] and volatility [55].

Vo, XV [39] provide evidence that foreign ownership improves stock price informativeness in emerging market (Vietnam). Hao et al. [56] provide conflicting evidence in emerging market (Taiwan), where they show that the informational efficiency of the market price actually declines even though the foreign institutional trading increases. This contra evidence in emerging market could be an interesting line of study for future research. Further, empirical evidence from emerging economy is necessary in understanding the role of foreign institutional investors on price informativeness, and the mechanisms through which this is achieved.

Empirical research to test key theories linking corporate governance is often done through construction of corporate governance index [14,57-62]. However, using index has its limitations because it is constructed using several attributes of governance with equal weights. Thus, studies using index have been criticised as it does not capture individual constituent attributes' specific contribution. Alternative methods using specific attributes of corporate governance has been suggested in literature $[63,64]$. This paper provides a review of theory and literature on three specific attributes of Board, the compensation, Independence and Board busyness and also provides a model for conducting further research.

\section{Executive Compensation}

Almazan, Hartzell, and Starks [65] develop theoretical models with the following propositions (1) "comparing the constraints faced by a manager when proposing compensation at $\mathrm{t}=\mathrm{l}$ : the salary limit, $\mathrm{K}$, and the fact that if the salary demand is excessive, institutional investors will attempt to replace the incumbent" (2) "The pay-for-performance sensitivity of the manager's compensation is: 1) non-decreasing in the total of the monitoring shareholder's ownership in the firm and 2) non-increasing in the ratio of that institutions' cost of monitoring to its probability of success" and (3) "The level of compensation: a) decreases (weakly) with the ownership of each class of institutional investor, b) increases (weakly) with the ratio of the cost of monitoring to its probability of success."

Compensation to the top management executives, especially the CEO [66-68], is a widely researched topic in corporate governance because the compensation has a direct impact on 
the wealth of the investors and is the essence of the agency problem. Further Benmelech et al. [69] argue that managers compensated through stocks choose sub-optimal investment policies and conceal negative news, which can eventually cause great wealth erosion when stock prices crash. AmoakoAdu et al. [70] shows that executive positions held by family members are compensated significantly higher in comparison to non-family member executives. Further, Harford and Li [71] find that the CEO is incentivised to undertake a value destroying acquisition if he anticipates increase in his postmerger compensation. There is an association with higher CEO pay with director busyness and board attendance problems [72-74]. Garner and Kim [75] study the impact of foreign ownership and pay-performance sensitivity in Korean firms under the emerging markets context and find that foreign institutional investors promote corporate governance through better monitoring. These studies suggest that board busyness of directors directly impact their ability to effectively monitor and advise managers. Even though there is a plethora of research papers which discuss the impact of foreign institutional investors on CEO compensation, there is paucity in studies establishing the impact of foreign institutional investors on the compensation of directors.

\section{Board Independence}

Ferreira et al. [50] provides a theoretical setup for board independence and price informativeness. According to the theory the shareholders' problem at date 0 is to maximize the expected value of the firm by choosing the level of monitoring of the board of directors the model specified by them. Thus the optimal degree of board independence varies with the degree of price informativeness.

The role of independent board has not only been a subject of interest in academic research but also finds its inclusion in several corporate legislations across the globe like Sarbanes Oxley Act 2002, USA and Companies Act 2013, India. These legislations were normally followed by similar requirements for listing in stock exchanges like in USA: NYSE in 2002, Nasdaq in 2003; and in India: SEBI clause 49 guidelines on Corporate Governance in 2005. In literature Ferreira et al. [50] finds a negative relation between board independence and stock price informativeness. Bertoni et al. [76] use resource-dependence and agency theories to provide evidence that board independence results in value-creation and valueprotection in young companies at the time of its initial public offering. Boone et al. [77] shows a negative relationship between manager's influence and board independence. While some studies show a positive relationship between board independence and corporate performance and improved informativeness [78-80], Vafeas [81] show contra evidence and Arslan et al. [82] argue that there is no impact of board independence on accounting performance.

Empirical studies provide evidence on a positive relationship between board independence and foreign institutional investors. Cremers and Nair [83] provide evidence of complementarity effects of foreign ownership and openness to corporate control. An independent board can provide corporate control on behalf of the market [8]. Literature shows that the impact of foreign institutional investors to be positive on board independence leading to significant changes in pay out and investment related policies [84].

While foreign investor tend to own companies which are more independent [85-87] and which as better governance [88], Ananchotikul [89] focused on Thailand, Aggarwal et al. [14] worked on developed markets (mostly European economies and USA) and Beatson et al. [90] work on chinese market show that foreign ownership can impact board independence. These evidences display problem of reverse causality endogeneity problem between board independence and foreign ownership which need to be addressed.

\section{Board Busyness}

Falato et al. [91] theory of director attention hypothesis, considers multi-tasking model of a director's optimal allocation of effort among different tasks. Accordingly, the higher a director's workload is, the less effort the director devotes to each of her duties. Thus, an increase in a director's workload should be costly for shareholders. A detailed model is discussed by Falato et al. [91] which shows that if the director's workload increases, the director's effort on any given activity falls.

Since Lipton and Lorsch [92] argued that a good governance demand at least one hundred hours per board appointment, the work load of directors has increased multi fold post Sarbanes-Oxley act [93]. This has led to overcommitted directors who may not be able to effectively monitor the managers and fulfil their duties. In literature the standard measurement of director busyness is the total number of outside directorships.

The busyness of the directors has several effects on the firm, literature provides mixed evidence regarding this. Falato et al. [91] provides the evidence that investors consider the work load of independent directors to be an important factor. While Falato et al. [91] provide evidence that directors' busyness is harmful to board monitoring quality and shareholder value, Fich and Shivdasani [74] show that lower market-to-book ratios are associated with busy directors.

There is evidence associating higher board busyness with lower firm valuations and less effective monitoring [72,74,94-96], on the contrary some studies show positive relationships [73,95,97,98] and additional board seats with better incentives results in positive stock returns [99].

When the 'workload effects' dwarfs director 'quality effects', the result is erosion of firm value. This results in more talented or reputable directors to be busy as they are more likely to hold multiple board positions [73], this is recognised as 'selection effects' [100]. Multiple directorships can serve as an endorsement of directors' abilities [101]. 


\section{Endogeneity Issues}

Implications of foreign ownership on the board characteristics (board compensation, independence and busyness) are not devoid of the contentious issue of endogeneity. These could be caused due to omitted variables, reverse causation or through heterogeneity issues. Several papers have used instrumental variables (IV hereon) and difference-in-difference (DiD hereon) quasi natural experiment approaches to address these issues. Chen et al. [67] use brokerage closures and brokerage mergers as exogenous variation in analyst coverage as their shock for DiD. Bena et al. [102] use fixed effects to control unobserved heterogeneity and stock additions/deletions to MSCI All Country World Index (MSCI ACWI) as an IV for the foreign institutional ownership. IV was also used by Aggarwal et al. [14] to address the endogeneity issue that foreign institutional investors might be attracted to firms that have higher governance. They use several IV like dividend payment dummy, membership in the Morgan Stanley Capital International All Country World index, share turnover for foreign ownership to check robustness of their results. To overcome endogeneity of board appointments, Hauser [103] use variation in board appointments induced by mergers. Following Aggarwal [14] IV approach can be used to address endogeneity issues. This can be validated using an exogenous shock for DiD method.

\section{Conclusion}

There are competing views on whether foreign institutional ownership has an influence on the corporate governance of the firm. One being that they play a monitoring role and the other being that they simply buy and sell for a profit. There is no conclusive evidence on both these views, especially in the emerging markets scenario. Thus, research studying the role of foreign institutional investment as a channel for promoting better governance in emerging economies with particular focus on the impact of foreign institutional investors on three main attributes of corporate governance, which are board independence, board busyness and board compensation, is an interesting literature gap for further research. Under the international portfolio diversification theory foreign institutional holdings has been increasing globally, however, there is very little empirical evidence on their implications on firm characteristics worldwide. Foreign institutional investors potentially influence firms into adopting better governance practices. This they do either by exercising their voting rights ("voice"), sell their shares ("voting with their feet") to show dissatisfaction, do nothing and be loyal or through relationship investing.

The research gap identified contributes to the literature of foreign institutional investors function in corporate governance practices in emerging markets, specifically the impact on certain board characteristics. There is a paucity of study in impact of foreign institutional investors on corporate governance in the emerging economics and with respect to the impact of specific types of foreign institutional owners. Future research can address these gaps and make specific contributions to the literature of impact of different foreign investor on corporate governance through board attributes (board independence, board busyness and director compensation) of emerging economies. The research can also look into the investor heterogeneity like look at differential impacts by different foreign investor classification like foreign promoter investors, foreign venture capital investors, foreign individual investors, foreign corporate investors and others.

\section{References}

1. Turnbull S. Corporate Governance: Its scope, concerns and theories. Corp Go. 1997;5(4):180-205.

2. Blair M. Ownership and Control. Brookings Institution Press. Washington, DC. 1995.

3. Donaldson L, Barney J. The Ethereal Hand: Organizational Economics and Management Theory; The Debate Between Traditional Management Theory and Organizational Economics: Substantive Differences or Intergroup Conflict? A Reply. Acad Manag Rev. 1990;15(3):369.

4. Tricker RI. International corporate governance: text, readings, and cases. Prentice Hall, NewYork, 1994.

5. Jensen MC, Meckling WH. Theory of the firm: Managerial behavior, agency costs and ownership structure. J Financial Econ. 1976;3(4):305-360.

6. Stulz RM. The Limits of Financial Globalization. J Finance. 2005;60(4):1595-1638.

7. Ni Y, Liao Y, Huang P. Foreign Institutional Investors, Shareholding Change, and Corporate Governance. Emerging Markets Finance and Trade. 2017; 53(4):764-775.

8. Gillan S, Starks L. Corporate Governance, Corporate Ownership, and the Role of Institutional Investors: A Global Perspective. J Applied Finance. 2003;13(2):4-22.

9. Borochin P, Yang J. The effects of institutional investor objectives on firm valuation and governance. J Financial Econ. 2017;126(1):171-199.

10. Yoshikawa T, Tsui-Auch LS, McGuire J. Corporate governance reform as institutional innovation: the case of Japan. Organ Sci. 2007;18(6): p: 973.

11. Fogel KS, Lee KK, Lee WY, et al., Foreign direct investors as change agents: The swedish firm experience. Corporate Governance (Oxford), 2013.

12. Boehmer E, Kelley EK. Institutional Investors and the Informational Efficiency of Prices. Rev Financial Stud. 2009;22(9):3563-3594.

13. Ferreira MA, Matos P. The colors of investors' money: The role of institutional investors around the world. J Financial Econ. 2008;88(3):499-533. 
14. Aggarwal R, Erel I, Ferreira M, et al. Does governance travel around the world? Evidence from institutional investors. J Financial Econ. 2011;100(1):154-181.

15. Boone AL, White JT. The effect of institutional ownership on firm transparency and information production. J Financial Econ. 2015;117(3):508-533.

16. Hartzell JC, Starks LT. Institutional Investors and Executive Compensation. J Finance. 2003;58(6):23512374.

17. Paramati SR, Ummalla M, Apergis N. The effect of foreign direct investment and stock market growth on clean energy use across a panel of emerging market economies. Energy Economics. 2016;56:29-41.

18. Barber BM, Odean T. All That Glitters: The Effect of Attention and News on the Buying Behavior of Individual and Institutional Investors. Rev Financial Stud. 2008;21(2):785-818.

19. Nagel S. Short sales, institutional investors and the cross-section of stock returns. J Financial Econ. 2005;78(2):277-309.

20. Sias RW, Starks LT. Return autocorrelation and institutional investors. J Financial Econ. 1997;46(1):103-131.

21. Lakonishok J, Shleifer A, Vishny RW. The impact of institutional trading on stock prices. J Financial Econ. 1992;32(1):23-43.

22. Helwege J, Intintoli VJ, Zhang A. Voting with their feet or activism? Institutional investors' impact on CEO turnover. J Corporate Finance. 2011.

23. Admati AR, Pfleiderer P. The "wall Street Walk" and shareholder activism: Exit as a form of voice. Rev Financial Stud. 2009;22(7):2645-2685.

24. Edmans A. Blockholder Trading, Market Efficiency, and Managerial Myopia. J Finance. 2009;64(6):2481-2513.

25. Edmans A, Manso G. Governance Through Trading and Intervention: A Theory of Multiple Blockholders. Rev Financial Stud. 2011;24(7):2395-2428.

26. Peng F, Kang L, Jiang J. Selection and institutional shareholder activism in Chinese acquisitions. Management Decision. 2013;51(1):141-162.

27. Zhou J, Lan W, Tang Y. The value of institutional shareholders. Management Decision, 2016;54(1):44-65.

28. Monks RAG. Relationship Investing. Corp Gov. 1994;2(2):58-76.

29. Murphy A, Kleiman R, Nathan, K. The Value of convertible preferred stock in transactions with "relationship investors" like Warren Buffett. Inter Review of Financial Analysis. 1997;6(3):241-256.

30. Merton RC. A Simple Model of Capital Market Equilibrium with Incomplete Information. J Finance. 1987;42(3):483-510.
31. Dahlquist M, Robertsson G. Direct foreign ownership, institutional investors, and firm characteristics. J Financial Econ. 2001;59(3):413-440.

32. Giannetti M, Simonov A. Which Investors Fear Expropriation? Evidence from Investors' Portfolio Choices. J Finance. 2006;61(3):1507-1547.

33. Huang W, Zhu T. Foreign institutional investors and corporate governance in emerging markets: Evidence of a split-share structure reform in China. J Corporate Finance. 2015;32(C):312-326.

34. Brockman P, Chung DY. Investor Protection and Firm Liquidity. J Finance. 2003;58(2):921-937.

35. Coffee J. Liquidity versus control: The institutional investor as corporate monitor. Colum L Rev. 1991;91(6):1277.

36. Bhide A. The hidden costs of stock market liquidity. J Financial Econ. 1993;34(1):31-51.

37. Maug E. Large Shareholders as Monitors: Is There a Trade off between Liquidity and Control? J Finance. 1998;53(1):65-98.

38. Kahn C, Winton A. Ownership Structure, Speculation, and Shareholder Intervention. J Finance. 1998;53(1):99-129.

39. Vo XV. Do foreign investors improve stock price informativeness in emerging equity markets? Evidence from Vietnam. Res Inter Business Finance. 2017;42:986-991.

40. Huang $\mathrm{P}$, Ni Y. Board structure and stock price informativeness in terms of moving average rules. Quarterly Review of Economics and Finance. 2017;63:161-169.

41. Armstrong CS, Balakrishnan K, Cohen D. Corporate governance and the information environment: Evidence from state antitakeover laws. J. Account Econ. 2012;53(12):185-204.

42. Dimitropoulos PE, Asteriou D. The effect of board composition on the informativeness and quality of annual earnings: Empirical evidence from Greece. Res Inter Business Finance. 2010;24(2):190-205.

43. Ding R, Hou W, Kuo JM, et al. Fund ownership and stock price informativeness of Chinese listed firms. J Multi Fin Manag. 2013;23(3):166.

44. He W, Li D, Shen J, et al. Large foreign ownership and stock price informativeness around the world. J Int Money Finance. 2013;36:211-230.

45. Massa M, Zhang L. Fire Sales and Information Advantage: When Informed Investor Helps. IDEAS Working Paper Series from RePEc. 2015.

46. Shleifer A, Vishny RW. A Survey of Corporate Governance. J Finance. 1997;52:737-783.

47. Smith MP. Shareholder Activism by Institutional Investors: Evidence from CalPERS. J Finance. 1996;51(1):227-252. 
48. Khanna T, Thomas C. Synchronicity and firm interlocks in an emerging market. J Financial Econ. 2009;92(2):182-204.

49. Batten JA, Vo XV. Liquidity and Return Relationships in an Emerging Market. Emerging Markets Finance and Trade. 2014;50(1):5-21.

50. Ferreira D, Ferreira MA, Raposo CC. Board structure and price informativeness. J Financial Econ. 2011;99(3):523545.

51. Ng L, Wu F, Yu J, et al. Foreign Investor Heterogeneity and Stock Liquidity around the World. Review of Finance. 2016;20(5):1867-1910.

52. Peranginangin Y, Ali AZ, Brockman P, et al., The impact of foreign trades on emerging market liquidity. PacificBasin Finance J. 2016;40:1-16.

53. Rhee SG, Wang J. Foreign institutional ownership and stock market liquidity: Evidence from Indonesia. J Bank Finance. 2009;33(7):1312-1324.

54. Chung CY, Kim H, Ryu D. Foreign investor trading and information asymmetry: evidence from a leading emerging market. Appl Econ Lett. 2017;24(8):540-544.

55. Vo, XV. Foreign ownership and stock return volatility-Evidence from Vietnam. J Multi Fin Manag. 2015;30:101-109.

56. Hao Y, Chou RK, Ho KY, et al., The impact of foreign institutional traders on price efficiency: Evidence from the Taiwan futures market. Pacific-Basin Finance J. 2015;34:24-42.

57. English PC, Smythe TI, McNeil CR. The "CalPERS effect" revisited. Journal of Corporate Finance. 2004;10(1):157-174.

58. Faisal, J. Impact of corporate governance index on firm performance: evidence from Pakistani manufacturing sector. J Gov Regul. 2015;4(3):163-174.

59. Hiraki T, Ito A, Kuroki F. Investor Familiarity and Home Bias: Japanese Evidence. Asia-Pacific Financial Markets. 2003;10(4):281-300.

60. Kim HJ. Toward the "best practice" model in a globalizing market: recent developments in Korean corporate governance. The J Corporate Law Studies. 2002;2(2):345.

61. Klapper LF, Love I. Corporate governance, investor protection, and performance in emerging markets. J Corporate Finance. 2004;10(5):703-728.

62. Stilpon N. The corporate governance crisis: An opportunity for emerging markets corporations? Inter Financial Law Rev. 2002;11-14.

63. Aggarwal R, Erel I, Stulz R, et al., Differences in Governance Practices between U.S. and Foreign Firms: Measurement, Causes, and Consequences. Rev Financial Stud. 2010;23(3):3131-3169.

64. Gompers P, Ishii J, Metrick A. Corporate governance and equity prices. Q J Econ. 2003;118(1):107-155.
65. Almazan A, Hartzell JC, Starks LT. Active Institutional Shareholders and Costs of Monitoring: Evidence from Executive Compensation. Financial Management. 2005;34(4):5-34.

66. Bebchuk LA, Cremers KJM, Peyer UC. The CEO pay slice. J Financial Econ. 2011;102(1):199-221.

67. Chen T, Harford J, Lin C. Do analysts matter for governance? Evidence from natural experiments. J Financial Econ. 201;115(2):383-410.

68. Masulis RW, Wang C, Xie F. Agency Problems at Dual Class Companies. J Finance. 2009;64(4):1697-1727.

69. Benmelech E, Kandel E, Veronesi P. Stock-based compensation and $\mathrm{CEO}($ dis $)$ incentives. Q J Econ. 2010;125(4):1769-1820.

70. Amoako-Adu B, Baulkaran V, Smith BF. Executive compensation in firms with concentrated control: The impact of dual class structure and family management. J Corporate Finance. 2011;17(5):1580-1594.

71. Harford J, Li K. Decoupling CEO Wealth and Firm Performance: The Case of Acquiring CEOs. J Finance. 2007;62(2):917-949.

72. Core JE, Holthausen RW, Larcker DF. Corporate governance, chief executive officer compensation, and firm performance. J Financial Econ. 1999;51(3):371-406.

73. Ferris SP, Jagannathan M, Pritchard AC. Too Busy to Mind the Business? Monitoring by Directors with Multiple Board Appointments. J Finance. 2003;58(3):1087-1111.

74. Fich EM, Shivdasani A. Are Busy Boards Effective Monitors? J Finance. 2006;61(2):689-724.

75. Garner JL, Kim WY. Are foreign investors really beneficial? Evidence from South Korea. Pacific-Basin Finance J. 2013;25(C): 62-84.

76. Bertoni F, Meoli M, Vismara S. Board Independence, Ownership Structure and the Valuation of IPOs in Continental E urope. Corp Gov. 2014;22(2):116-131.

77. Boone AL, Casares FL, Karpoff JM, et al. The determinants of corporate board size and composition: An empirical analysis. J Financial Econ. 2007;85(1):66-101.

78. Klein A. Audit committee, board of director characteristics, and earnings management. J Account Econ. 2002;33(3):375-400.

79. Petra ST. The Effects of Corporate Governance on the Informativeness of Earnings. Econ Gov. 2007;8(2):129.

80. Ponnu C, Karthigeyan R. Board independence and corporate performance: Evidence from Malaysia. Afr J Bus Manage. 2010;4(6):858-868.

81. Vafeas N. Board structure and the informativeness of earnings. J Account Public Policy. 2000;19(2):139-160.

82. Arslan O, Karan M, Eksi C. Board Structure and Corporate Performance. Managing Global Transitions. 2010;8(1):3-22. 
83. Cremers KJM, Nair VB. Governance Mechanisms and Equity Prices. J Finance. 2005;60(6):2859-2894.

84. Jeon JQ. How do foreign investors affect corporate policy? Evidence from Korea. Inter Rev Econ Finance. 2013;25:52-66

85. Miletkov MK, Poulsen AB, Babajide Wintoki M. The role of corporate board structure in attracting foreign investors. J Corp Finance. 2014;29:143-157.

86. Neupane S, Neupane B. Board structure and institutional ownership at the time of IPO. Managerial Finance. 2017;43(9):950-965.

87. Saad Al-shamahi, MGM. The Effect of Corporate Board Structure on Foreign Share Ownership: Listed Companies in Gulf Cooperation Council (GCC) Countries. Inter J Business \& Innovation. 2018;4(1):14-27.

88. Leuz C, Lins KV, Warnock FE. Do Foreigners Invest Less in Poorly Governed Firms? Rev Financial Stud. 2010;23(3):3245-3285.

89. Ananchotikul N. Does Foreign Direct Investment Really Improve Corporate Governance? Evidence from Thailand. IDEAS Working Paper Series from RePEc. 2008.

90. Beatson SA, Chen J. Foreign investment, corporate governance and performance in the Chinese listed A Share companies. J Chinese Economic and Business Studies. 2018;16(1): 59-93.

91. Falato A, Kadyrzhanova D, Lel U. Distracted directors: Does board busyness hurt shareholder value? J Financial Econ. 2014;113(3):404.

92. Lipton M, Lorsch J. A Modest Proposal for Improved Corporate Governance. The Business Lawyer. 1992;48(1):59.

93. Linck JS, Netter JM, Yang T. The Effects and
Unintended Consequences of the Sarbanes-Oxley Act on the Supply and Demand for Directors. Rev Financial Stud. 2009;22(8):3287-3328.

94. Ahn S, Jiraporn P, Kim YS. Multiple directorships and acquirer returns. J Bank Finance. 2010;34(9):2011-2026.

95. Field L, Lowry M, Mkrtchyan A. Are busy boards detrimental? J Financial Econ. 2013;109(1):63-82.

96. Shivdasani A, Yermack D. CEO Involvement in the Selection of New Board Members: An Empirical Analysis. J Finance. 1999;54(5):1829-1853.

97. Loderer C, Peyer U. Board Overlap, Seat Accumulation and Share Prices. Eur Financial Management. 2002;8(2):165-192.

98. Masulis RW, Mobbs S. Are All Inside Directors the Same? Evidence from the External Directorship Market. J Finance. 2011;66(3):823-872.

99. Perry T, Peyer, U. Board Seat Accumulation by Executives: A Shareholder's Perspective. J Finance. 2005;60(4): 2083-2123.

100. Adams RB, Hermalin BE, Weisbach MS. The Role of Boards of Directors in Corporate Governance: A Conceptual Framework and Survey. J Econ Lit. 2010;48(1):58-107.

101. Fama EF, Jensen MC. Separation of ownership and control. (includes bibliography) (Corporations and private property: Hoover Institution conference Nov. 19-20, 1982). J Law and Economics. 1983;26(2):301325.

102. Bena J, Ferreira MA, Matos P. Are foreign investors locusts? The long-term effects of foreign institutional ownership. J Financial Econ. 2017;126(1):122-146.

103. Hauser R. Busy directors and firm performance: Evidence from mergers. J Financial Econ. 2018;128(1):16-37.

\section{*Correspondence to:}

Sandeep Rao

Department of Accounting and Finance

Strathclyde Business School

University of Strathclyde, Glasgow

United Kingdom

E-mail: Sandeep.keshava-rao@strath.ac.uk 